\title{
MS4A2 Gene
}

National Cancer Institute

\section{Source}

National Cancer Institute. MS4A2 Gene. NCI Thesaurus. Code C101623.

This gene is involved in immunoglobulin binding. 